\title{
Complete Mitochondrial Genomes of Babylonia Formosae and Babylonia Zeylanica (Neogastropoda: Babyloniidae) and Increased Sampling Give New Insights Into Neogastropoda Phylogeny
}

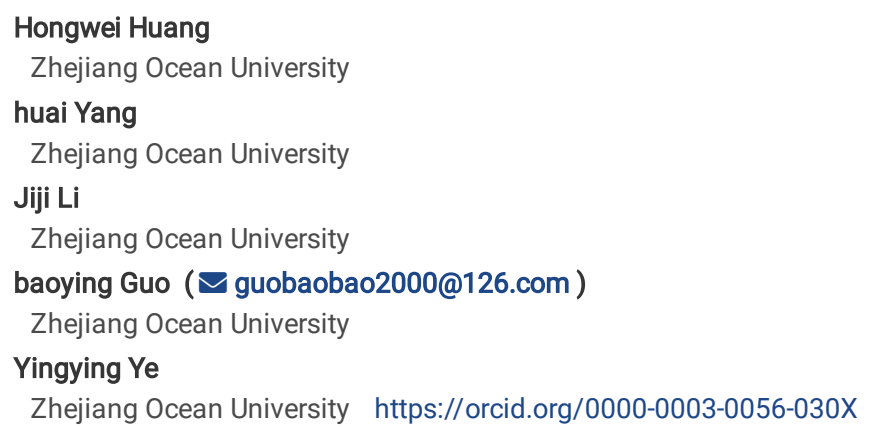




\section{Abstract}

The phylogenetic relationships of Neogastropoda, a group of highly complex predatory marine snails, have been controversial. The two newly sequenced mitogenomes of Babylonia formosae and Babylonia zeylanica (Neogastropoda: Babyloniidae) are described. The mitogenomes of $B$. zeylanica and $B$. formosae were 16, 214 bp and 16, 181 bp in length, respectively. The mitogenomes of both species contain 13 PCGs, 22 tRNA genes, and 2 ribosomal RNA genes. The sequence of genes differed from the ancestral mitochondrial gene arrangement of Caenogastropoda mitogenomes. Also, 63 Neogastropoda species were analyzed for the genome organization of seventeen major lineage of Neogastropoda, five types of mitochondrial genome arrangement were identified. Bayesian Inference phylogenetic trees and Maximum likehood of Neogastropoda were established according to complete mitogenome. The monophyly of Neogastropoda families is strongly supported by this study, in contrast to previous molecular studies. Our results shed light on gene sequence distribution/arrangement characteristics of Neogastropoda mitogenomes, provide fundamental information for further phylogenetic studies on Neogastropoda.

\section{Introduction}

Metazoan Mitogenome (mtDNA) is a small ( 14 to $20 \mathrm{~kb}$ ) circular genome, containing 37 genes, which were divided into three parts, including 2 ribosomal RNA genes (rRNA), 2 transfer RNA genes (tRNA), and 13 protein-coding genes (PCGs) [1]. The gene arrangement was first thought to be generally conserved [23], can provide crucial information regarding phylogenetic relationships in Metazoa [4-6].

Generally, gene rearrangements are thought to be more common in invertebrate mitogenomes, such as in sea cucumbers [7], cephalopods [8], bivalves [9], insects [10], and crabs [11]. Because gene order of closely related species is assumed to be relatively conserved, it has been increasingly used as a valuable molecular marker to infer evolutionary lineage relationships [12-13]. Indeed, in Caenogastropoda, one of the four vital lineages of gastropod that accounts for presumably $60 \%$ of the total known living marine gastropod species [14], three studies of mtDNA rearrangement have been showed in previous study [15-16]. Namely, a translocation between the tRNA ${ }^{\mathrm{Val}}$ genes and tRNA ${ }^{\mathrm{Ser}}(\mathrm{UCN})$ [16], and four different vermetid species shows, a translocation of the tRNA ${ }^{\text {Lys }}$ gene, and a translocation between a fragment of tRNA ${ }^{\text {Pro }}$ and subunit 6 of NADH dehydrogenase [17].Considering the increased sampling give new insights into the mitochondrial genome organization of Neogastropoda, during the development of the gastropod system, comprehensive sequencing in mitochondrial genomes is needed for figuring out their gene arrangements.

Four important scientific hypotheses have been advanced in order to interpret gene rearrangement events. Recombination model characterized by DNA fragmentation and reconnection DNA breakage and rejoining was the first proposed hypothesis. As a mechanism of mitochondrial gene rearrangement, it has been proposed in frog, bird, and mussels [18-20]. Another well-known hypothesis is tandem duplication and random loss (TDRL) model. In this model, it is assumed that the rearrangements occur in both tandem and segmental duplications of some genes in the mitogenome, which are subsequently followed by random removal of duplicates [7,21]. Most of whole genome rearrangements in vertebrate species were predated and well-explained by this model [22-24]. It has been proposed that tandem duplication and non-random (TDNL) model could explain gene arrangements observed in two millipede mitogenomes [25]. Finally, the new double replications and random loss (DRRL) model has been recently proposed to explain the large-scale genome rearrangements diffusely in the flatfish Samariscus latus (Samaridae) [26].

Neogastropoda was widely considered as a monophyletic group among morphologists However, the evolutionary relationships among Neogastropoda families based solely on morphological characters are precarious. Current research, based on molecular studies, usually do not support this classification system of monophyly of Neogastropoda [27-32]. For example, (a research presents a novel classification model that divides Neogastropoda into six superfamilies: Muricoidea, Pseudolivoidea, Buccinoidea, Olivoidea, Cancellarioidea, and Conoidea. Another study by Harasewych et al. reports that Neogastropoda is not a monophyletic group based on the analysis of partial COI and 16S rRNA sequences.

Some studies have shown that mitogenomic rearrangements can provide significant information about the origin and evolution [33-35]. In the current research, we have sequenced and identified the whole mitogenomes of $B$. formosae and $B$. zeylanica, to uncover the mitogenomic rearrangements and the evolution within Neogastropoda. The order of genes in B. formosae and B. zeylanica mitogenomes were compared with other Neogastropoda mitogenomes, and underlying rearrangement mechanisms were analyzed and dissected. The mitogenome sequences of 63 species representing 17 families of Neogastropoda were downloaded from the GenBank database to structure the phylogenetic tree. Our findings shed light on the gene arrangement features of Neogastropoda mitogenomes and provide fundamental information for further evolutionary studies on Neogastropoda.

\section{Materials And Methods}

\section{Sampling, DNA Extraction, PCR Amplification and Sequencing}

Babylonia formosae and B. zeylanica used in this study were obtained from Hainan, China $\left(20^{\circ} 03^{\prime} \mathrm{N} ; 110^{\circ} 32^{\prime} \mathrm{E}\right)$ and Guangdong, China $\left(23^{\circ} 35^{\prime} \mathrm{N}\right.$; $\left.116^{\circ} 68^{\prime} \mathrm{E}\right)$ respectively and immediately preserved in 95\% ethanol. Genomic DNA was extracted from adductor musculature using the SQ Tissue DNA Kit (OMEGA) following the manufacturer's protocol and stored at $-20^{\circ} \mathrm{C}$ before sequencing.Complete mitogenome sequences were amplified in each sample and the results were compared with the existing sequences in GenBank database for final identification of the species.

\section{Sequence Assembly, Annotation and Analysis}

The sequences were assembled and analyzed via Illumina genetic analyzer by Origingene Bio-pharm Technology Co., Ltd., (Shanghai, China). NOVOPlasty (https://github.com/ndierckx/NOVOPlasty) stitching software was used to join together multiple iterations of sequenced fragments to obtain optimal assembly results. All assembled B. formosae and B. zeylanica mitochondrial genes were aligned with Babylonia lutosa (KF897830.1) identified by BLAST, 
after verification of sequences in the NCBI database. In addition, relevant information about mitogenome was annotated by Sequin software (version 15.10 http://www.ncbi.nlm.nih.gov/Sequin/). The boundaries of the 13 protein coding genes (PCGs) and 2 ribosomal RNA (rRNA) genes were verified using NCBIBLAST (http://blast.ncbi.nlm.nih.gov). The secondary structure of tRNA genes were predicted using both the MITOS Web Server [36] and tRNAscan-SE 1.21 [37]. The final mitogenome map was produced using CGView [38]. The base composition of mitogenomes was acquired using MEGA X [39]. To examine strand asymmetry, the AT-skew and GC-skew values were calculated using the formulas: AT-skew $=(A-T) /(A+T) ; G C-s k e w=(G-C) /(G+C)[40]$.

\section{Phylogenetic Analyses}

Sixty-three Neogastropoda mitogenomes were downloaded from the GenBank (https://www.ncbi.nlm.nih.gov/genbank/) for phylogenetic analysis (Table.1). Lepetellida and Patellogastropoda have been thought to be closely related to Neogastropoda, hence, one Patellogastropoda and two Lepetellida species, Lottia digitalis, Haliotis rufescens and Haliotis rubra, were chosen as the outgroup. Fasta files containing nucleotide sequence for all 13 PCG genes were retrieved from GenBank using PhyloSuite [41]. Nucleotide sequence alignments were performed using MAFFT [42] in the default configuration, and were manually checked with BioEdit [43]. Sequences containing ambiguous bases were systematically discarded using Gblock [44]. Subsequently, all alignments were concatenated into single fasta and nexus format files for phylogenetic analyses. Phylogenetic analyses were inferred using Maximum Likelihood (ML) and Bayesian Inference (BI). ML phylogenetic inference was performed using IQ-TREE [45], using 1000 rapid bootstrap replications under the GTR+F+R6 model. BI analysis was conducted in MrBayes 3.2.6 [46], with the best-fit GTR+l+G models selected from 24 models using MrModelTest 2.3 [47]. BI analyses were implemented using general Lset values (e.g., nst and rates) allowing the program to converge on the best estimates of the model parameters. BI analyses were run for 2,000,000 generations, sampling trees every 100 generations, for a total of 20,000 trees sampled. Four chains, three heated (temperature $=0.5$ ) and one cold, were simultaneously run using Metropolis-coupled Markov chain Monte Carlo (MCMCMC) to enhance the mixing capabilities of the Markov chains. To guarantee the stationary had been reached, the average standard deviation of split frequencies was set below 0.01 .

\section{Results}

\section{Genomic Characteristics}

The complete mitogenomes of $B$. formosae and B. zeylanica were 16, 214 bp and 16, 181 bp in length, respectively (GenBank accession number MK577482 and MN604402). This is close to the size of the other Babylonia mitogenomes that have previously been published (15, 346 bp for $B$. lutosa (KF897830.1) and 15, 445 bp for Babylonia areolata (HQ416443.1)) (Table 1). All of these mitogenomes comprised 22 tRNAs, 13 PCGs, and two rRNAs (Fig.1A-B, Table 2). The total length for the 13 PCGs of $B$. formosae and B. zeylanica were 10, $806 \mathrm{bp}$ and 11, $247 \mathrm{bp}$, respectively. Most of genes are encoded by the H-strand except for the tRNA genes trnC, trnE, trnG, trnM, trnQ, trnT, trnW, and trnY, encoded by the L-strand. The PCGs ranged in size from 264 bp (ND4L) to 1671 bp (ND5) in B. formosae, and from 159 bp (ATP8) to 1731 bp (ND5) in B. zeylanica (Table 2). Ten PCGs (ND1, ND2, ND3, ND4, ND4L, COI, COIl, ATP8, ATP6, and Cytb) use the typical ATG start codon, with the exception of ND5, ND6, and CoIll genes in the $B$. formosae mitochondrial genome. And ND6, ND4, ND5, and ND2 in B. zeylanica, starting with the alternative start codon ATT. The termination codons in PCGs were either TAA or TAG in these two mt genomes (Table 3 ).

\section{Skewnes and Composition}

Three values (GC-skew, AT-skew, and A+T content) are usually used to assess the whole DNA sequences composition. These statistics were calculated for the newly sequenced PCGs in B. formosae and B. zeylanica mitogenomes. The A+T content of ATP8 (70.52\%) is the highest and A+T content of COX3 (59.82\%) is the lowest ATP8 (70.52\%) and the lowest in COX3 (59.82\%). The GC-skews are from-0.227 (ND5) to 0.222 (ND3) in the $B$. formosae genome, and the GC-skews are from -0.232 (ND6) to 0.256 (ND3) in the B. zeylanica mitogenome. All AT-skews are negative in both mitogenomes (Table 2). For $B$. formosae and $B$. zeylanica, the mtDNA A+T\% was $65.41 \%$ and $66.32 \%$, respectively, showing a noticeable AT bias. Coding regions accounted for $66.6 \%$ and $65.52 \%$ in these respective mtDNA, whereas non-coding region lengths were respectively 3,764 and 1,175 bp, distributed in 24 regions of the mitochondrial genome, accounting for $23.2 \%$ and $7 \%$ of total length.

\section{tRNA Secondary Structure}

In all Babylonia mt genomes, as in B. formosae and B. zeylanica, the tRNAs ranged from 65 to $70 \mathrm{bp}$ in length (in length ranged from 65 bp to $70 \mathrm{bp}$ ). Most of the predicted tRNAs conform to the expected structure with the canonical cloverleaf structures (Fig. 2). Departing from the canonical structure, trnS1 and trnS2 did not have a dihydrouridine (DHU) stem and the DHU arm simply formed a loop, and in trnF, the T $\psi \mathrm{C}$ arm did not form a loop. A similar DHU stem-loss phenomenon was generally observed in stoneflies and $\mathrm{mt}$ genomes of other insects [48-49]. The secondary structures presented a high degree of structural synteny in the two Babylonia mt genomes, trnD was identical in the two genomes and most tRNAs (fourteen out of 22) had fewer than five nucleotide differences between the two genomes. In contrast, the trnS2 and trnT had the highest number of variation, with more than 10 indels or substitutions in trnT, and nucleotide insertion-deletion in trnS2 and trnT (Fig. 2). The anticodon arm of these tRNAs was the most highly conserved region while the DHU arm and the TUC arm variable loop had the greater degree of variability in nucleotide substitutions or indels.

\section{Gene Arrangement of Major Lineage of Neogastropoda}

The gene sequence of Caenogastropoda consensus is quire resembles two reported in Neritimorphs and Vetigastropods, the latter of which had the closest to the ancestral mollusc gene order in gastropods. Herein, the gene arrangements of 63 taxa in 17 Neogastropoda families were compared with the hypothetical ancestral Caenogastropoda (Fig.3). The gene orders of the newly sequenced mt genomes were consisted with the most common Neogastropoda mt genomes (Type I). Within Neogastropoda, minor differences of Fusiturris similis and Oxymeris dimidiate regarding the consensus gene order were founded. The former differs in the relative position of the trnS (Type III), and the latter differs in the relative position of the trnV (Type IV). The most notable finding was the essential 
difference between Clavatula tripartita of Clavatulidae and Profundiconus teramachii of Conidae, which the trnF gene was lost in the two mitochondrial genomes (Type II and V). Moreover, the relative position of the trnS in C. tripartita mt genome was also altered in compared to the consensus gene order.

\section{Phylogenetic Analysis}

To investigate the monophyly of major lineage Neogastropoda families, and analyze the phylogenetic position of $B$. formosae and $B$. zeylanica within Neogastropoda, both $\mathrm{BI}$ and $\mathrm{ML}$ trees were structured, using 63 species of Neogastropoda belonging to 17 families, and (using 63 species of Neogastropoda) as outgroup, two Littorinimorpha and one Lepetellida species (Fig.4). The tree results displayed that the phylogenetic patterns between the BI and ML trees were highly congruent. And the BI tree had most valuable data (Fig.4). Both phylogenetic trees obviously demonstrated that $B$. formosae and $B$. zeylanica have the closest relationship with $B$. lutosa and Babylonia areolata, and all four Babylonia species formed a Babyloiidae clade. Our results suggest that Babyloiidae was closely associated with Costellariidae and Volutidae. Of the 17 families included in this phylogenetic tree and each of them formed a monophyletic group. At the level of surperfamilies, each surperfamilies also formed a monophyletic group.

\section{Discussion}

\section{Mitochondrial Gene Arrangements}

To dissect the gene arrangement of seventeen major lineage of Neogastropoda, we compared the gene order of 63 taxa of 17 Neogastropoda families, including Babayloniidae, Drilliidae, Turridae, Cancellariidae, Costellariidae, Buccinidae, Melongenidae, Nassariidae, Muricidae, Volutidae, Fasciolariidae, Ancillariidae, Conidae, Columbellidae, Terebridae, Fusiturridae and Clavatulidae (Fig.3). Compared with the putative Caenogastropoda ancestor mitochondrial genome Caenogastropoda, our results show that 59 species of 14 Neogastropoda families have the same gene order, which shows a relatively stable gene order, where the genes were located on the heavy chain, only eight genes that are in the light (minus) chain are included in the cluster of tRNAs MYCWQGE and tRNA-Thr (T). Except $P$. teramachii, specie of Conidae, which trnF gene was lost. However, compared with the most common rearrangement within Neogastropoda, a slight difference in the order of shared genes was found, in F. similis, $O$. dimidiate, and $C$. tripartite of the Fusiturridae, Terebridae and Clavatulidae families, only certain tRNA sequences exhibit translocation (trnV), inversion (trnS) and deletion (trnF), The first two gene arrangements are as previously reported [16,50]. Also, the comparisons of genomes within major lineage of Neogastropoda, in this study, we compared the 63 gene arrangement patterns in Neogastropoda, and found that protein-coding and rRNA gene rearrangements were not be known. These results were in accordance with the findings reported in bees [51]. Herein, 63 Neogastropoda species were analyzed for the genome organization of seventeen major lineage of Neogastropoda, five types of mitochondrial genome arrangement were identified, which shed a more systematic understanding for Neogastropoda.

\section{Monophyly of Neogastropoda}

Within the megadiverse phylum Mollusca, the Gastropoda is among the most widespread and abundant, surpassing 10,000 living species. The monophyly of the group is becoming more generally accepted among morphologists because its members share several critical morphological traits [52-53]. The majority of the molecular studies were concentrated on all gastropod species [29-30,32] or caenogastropoda [31] phylogeny, and only included a limited number of Neogastropods. Previous Neogatropod phylogeny studies were only based on certain gene segments. The monophyly of Neogastropoda remains unset in both molecular-based phylogenies and morphological. Cunha et al. (2009) suggested that shared morphological features of Neogastropoda are homoplasious, and molecular datasets analysis often do not contain adequate information to address the current phylogenetic question.

To further explore the monophyly of seventeen major lineage Neogastropoda families and the phylogenetic position of $B$. formosae and $B$. zeylanica within Neogastropoda, we generated two well-supported phylogenetic trees (Bayesian Inference phylogenetic trees and Maximum likehood). The two trees shown all Neogastropoda species clustered into the 17 families included in this phylogenetic analysis, each family in the phylogenetic tree forming a strongly supported monophyletic group with high bootstrap value or the Bayesian posterior probability, supporting monophyletic origins. Therefore, our research results demonstrated that these families were monophyletic. Our phylogenetic analysis based on complete mitochondrial genome sequence and increased neogastropod sampling within Nogastropoda lineages confirms the monophyly of Neogastropoda. This directly refutes previous molecular analyses [16,29,31-32] and confirms the correctness of morphological homology that generally support Neogastropoda as monophyletic [14,53]. Our phylogenetic framework within Nogastropoda outlined by a large number of ingroups is more suitable to test the monophyly of Neogastropoda.

\section{Phylogenetic Relationships}

The superfamily classification in this study follows Cunha et al. (2009). Here邓the two representative mitochondrial genomes from the unassigned superfamily (Neogastropoda: Babyloniidae) are obtained using next-generation sequencing. For this study, Babyloniidae (including B. lutosa, B. areoiata, B. formosae and B. zeylanica) together with a basal position relative to the remaining Neogastropods in both $\mathrm{BI}$ and $\mathrm{ML}$ nucleic acid analyses. Moreover, all the ML and BI analyses strongly supported the monophyly of Volutoidea, Olivoidea, Turbinelloidea, Muricoidea, Buccinoidea and Conoidea. Recent phylogenetic molecular analyses have proven that Conoidea is also a monophyletic group. Muricoidea was not found to be a monophyletic group in previous studies based on a combination of morphological and molecular data $[16,31,54]$. It forms two major monophyletic clades, sometimes together with Volutoidea and Olivoidea, with high support within Neogastropoda. Within the major clade in $\mathrm{ML}$ and BI trees, a monophyletic group containing Columbellidae, Fasciolariidae and Nassariidae is recognizable. Previous morphological and molecular studies are not large enough to test the monophyly of Buccinoidea [16,31]. Here, Buccinoidea is recovered as monophyletic, and also forms a monophyletic group together with five superfamilies, including Turbinelloidea, Volutoidea, Olivoidea, Conoidea and Muricoidea. Our results are nearly consistent with previous reports on Oliverio and Modica [55]. The classification of each family within Neogastropoda is strongly supported in all phylogenetic analyses at a lower taxonomic level. The evolutionary relationshisps among members of the Neogastropoda families remain quite blurry [56]. In Hayashi and Oliverio and Modica, Buccinidae is also found as paraphyletic or polyphyletic. However, seventeen major lineage of Neogastropoda are recovered as monophyly in our analyses. As a highly diversified group of predatory marine snails, 
Neogastropoda, has often been contradicted in molecular phylogenetic studies. This is partly due to the limited Neogastropoda taxa, outgroups or insufficient gene sequences analysis. For the first time, we reconstructed a phylogeny of major lineage of Neogastropoda including a total of $63 \mathrm{mt}$ genomes that represent the main lineages within the group. Our results can provide complementary results in previous phylogenetic analysis. Based on the complete mitochondrial genome data and increased sampling, our phylogenetic analyses also shed a new light on the major lineage of Nogastropoda phylogenetic framework and the phylogenetic relationships within Neogastropoda. Despite the uncomplete taxonomic coverage in the present analysis, it is a further research into Neogastropoda phylogenetic relationships, taking into account the complete mitochondrial genome of more than half of the family-level diversity of the Neogastropoda. However, considering the limited representatives of mitochondrial genomes in each superfamily of Neogastropoda, a more densely taxon sampling is needed in future studies. The more comprehensive sampling from these families will help elucidate these relationships.

\section{Declarations}

\section{Data Availability}

The complete mitogenomes of Babylonia formosae and Babylonia zeylanica has been submitted to GenBank under the accession number of MK577482 and MN604402.

\section{Acknowledgments}

This study was supported by NSFC Projects of International Cooperation and Exchanges (42020104009), National Natural Science Foundation of China (41976111 and 42076119) and Project of the Zhoushan City Science and Technology Bureau (2018C21015).

\section{Compliance with ethical standards}

\section{Conflict of Interest Statement}

The authors report no conflicts of interest. The authors alone are responsible for the content and writing of the paper.

\section{Ethical approval}

All applicable international, national, and/or institutional guidelines for the care and use of animals were followed by the authors.

\section{Author Contributions}

$\mathrm{HH}$ analyzed the data, wrote the paper, and prepared the figures and tables. HY and JL collected field material and processed the samples. YY conceived and designed the experiments, reviewed drafts of the paper. BG supervised and directed the work. All authors reviewed the manuscript.

\section{References}

1. Boore JL (1999) Animal mitochondrial genomes. Nucleic Acids Research 27(8):1767-1780.

2. Sato M , Sato K (2013) Maternal inheritance of mitochondrial DNA by diverse mechanisms to eliminate paternal mitochondrial DNA. Biochimica et Biophysica Acta (BBA)-Molecular Cell Research 1833, 1979-1984 .

3. Gyllensten U, Wharton D, Josefsson A, Wilson AC (1991) Paternal inheritance of mitochondrial DNA in mice. Nature 352, $255-257$.

4. Zhuang X, Cheng (2010) C. H. C. ND6 gene "lost" and found: evolution of mitochondrial gene rearrangement in Antarctic notothenioids. Molecular Biology and Evolution 27, 1391-1403.

5. Liu Y , Cui Z (2010) Complete mitochondrial genome of the Asian paddle crab Charybdis japonica (Crustacea: Decapoda: Portunidae): gene rearrangement of the marine brachyurans and phylogenetic considerations of the decapods. Molecular Biology Reports 37, $2559-2569$.

6. Xin ZZ (2017) Mitochondrial genome of Helice tientsinensis (Brachyura: Grapsoidea: Varunidae): Gene rearrangements and higher-level phylogeny of the Brachyura. Gene 627, 307-314.

7. Arndt A, Smith M (1998) Mitochondrial gene rearrangement in the sea cucumber genus Cucumaria. Molecular Biology and Evolution 15, $1009-1016$.

8. Jiang L, Kang L, Wu C, Chen M, Lü Z (2018) A comprehensive description and evolutionary analysis of 9 Loliginidae mitochondrial genomes. Hydrobiologia. 808, 115-124.

9. Wu X (2012) New features of Asian Crassostrea oyster mitochondrial genomes: a novel alloacceptor tRNA gene recruitment and two novel ORFs. Gene $507,112-118$.

10. Liu QN (2017) A transfer RNA gene rearrangement in the lepidopteran mitochondrial genome. Biochemical and Biophysical Research Communications 489, 149-154.

11. Wang Z (2018) Complete mitochondrial genome of Parasesarma affine (Brachyura: Sesarmidae): Gene rearrangements in Sesarmidae and phylogenetic analysis of the Brachyura. International Journal of Biological Macromolecules 118, 31-40.

12. Boore JL, Brown WM (1998) Big trees from little genomes: mitochondrial gene order as a phylogenetic tool. Current Opinion in Genetics \& Development 8 , 668-674.

13. Lavrov DV, Lang BF (2005) Poriferan mtDNA and animal phylogeny based on mitochondrial gene arrangements. Systematic Biology 54, $651-659$.

14. Ponder W, Lindberg DR (2008) Phylogeny and Evolution of the Mollusca. (University of California Press. 
15. Rawlings TA, Collins TM, Bieler R (2001) A major mitochondrial gene rearrangement among closely related species. Molecular Biology and Evolution 18, 1604-1609.

16. Cunha RL, Grande C, Zardoya R (2009) Neogastropod phylogenetic relationships based on entire mitochondrial genomes. BMC Evolutionary Biology 9 , 210.

17. Rawlings TA, Collins TM, Bieler R (2003) Changing identities: tRNA duplication and remolding within animal mitochondrial genomes. Proceedings of the National Academy of Sciences 100, 15700-15705.

18. Sammler S, Bleidorn C, Tiedemann R (2011) Full mitochondrial genome sequences of two endemic Philippine hornbill species (Aves: Bucerotidae) provide evidence for pervasive mitochondrial DNA recombination. BMC Genomics 12, 35.

19. Ladoukakis ED, Zouros E (2001) Recombination in animal mitochondrial DNA: evidence from published sequences. Molecular Biology and Evolution 18, 2127-2131.

20. Kurabayashi A (2008) Phylogeny, recombination, and mechanisms of stepwise mitochondrial genome reorganization in mantellid frogs from Madagascar. Molecular Biology and Evolution 25, 874-891.

21. Moritz C, Dowling T, Brown W (1987) Evolution of animal mitochondrial DNA: relevance for population biology and systematics. Annual review of ecology and systematics $18,269-292$.

22. Inoue JG, Miya M, Tsukamoto K, Nishida M (2003) Evolution of the deep-sea gulper eel mitochondrial genomes: large-scale gene rearrangements originated within the eels. Molecular Biology and Evolution 20, 1917-1924.

23. Schirtzinger EE (2012) Multiple independent origins of mitochondrial control region duplications in the order Psittaciformes. Molecular Phylogenetics and Evolution 64, 342-356.

24. San Mauro D, Gower DJ, Zardoya R, Wilkinson M (2006) A hotspot of gene order rearrangement by tandem duplication and random loss in the vertebrate mitochondrial genome. Molecular Biology and Evolution 23, 227-234.

25. Lavrov DV, Boore JL, Brown WM (2002) Complete mtDNA sequences of two millipedes suggest a new model for mitochondrial gene rearrangements: duplication and nonrandom loss. Molecular Biology and Evolution 19, 163-169.

26. Shi W, Miao XG, Kong XY (2014) A novel model of double replications and random loss accounts for rearrangements in the Mitogenome of Samariscus latus (Teleostei: Pleuronectiformes). BMC Genomics 15, 352.

27. Harasewych MG (1997) Neogastropod phylogeny: a molecular perspective. Journal of Molluscan Studies 63, 327-351.

28. Harasewych MG, Adamkewicz SL, Plassmeyer M, Gillevet PM (1998) Phylogenetic relationships of the lower Caenogastropoda (Mollusca, Gastropoda, Architaenioglossa, Campaniloidea, Cerithioidea) as determined by partial 18S rDNA sequences. Zoologica Scripta 27, 361-372.

29. Winnepenninckx B, Steiner G, Backeljau T, De Wachter R (1998) Details of gastropod phylogeny inferred from 18S rRNA sequences. Molecular Phylogenetics and Evolution 9, 55-63.

30. Colgan DJ, Ponder WF, Beacham E, Macaranas JM (2003) Molecular phylogenetic studies of Gastropoda based on six gene segments representing coding or non-coding and mitochondrial or nuclear DNA. Molluscan Research 23, 123-148.

31. Colgan DJ, Ponder WF, Beacham E, Macaranas J (2007) Molecular phylogenetics of Caenogastropoda (gastropoda: Mollusca). Molecular Phylogenetics and Evolution 42, 717-737.

32. McArthur AG, Harasewych MG (2003) Molecular systematics of the major lineages of the Gastropoda. Molecular Systematics and Phylogeography of Mollusks.

33. Inoue JG, MiyaM, Tsukamoto K, Nishida M (2001) Complete mitochondrial DNA sequence of Conger myriaster (Teleostei: Anguilliformes): novel gene order for vertebrate mitochondrial genomes and the phylogenetic implications for anguilliform families. Journal of Molecular Evolution 52, $311-320$.

34. Smith MJ, Arndt A, Gorski S, Fajber E (1993) The phylogeny of echinoderm classes based on mitochondrial gene arrangements. Journal of Molecular Evolution 36, 545-554.

35. Schierup MH, Hein J (2000) Consequences of recombination on traditional phylogenetic analysis. Genetics 156, $879-891$.

36. Bernt M (2013) MITOS: improved de novo metazoan mitochondrial genome annotation. Molecular Phylogenetics and Evolution 69, $313-319$.

37. Lowe TM, Chan PP (2016) tRNAscan-SE On-line: integrating search and context for analysis of transfer RNA genes. Nucleic Acids Research 44 , W54-W57.

38. Stothard P, Wishart DS (2005) Circular genome visualization and exploration using CGView. Bioinformatics 21, 537-539.

39. Kumar S, Stecher G, Li M, Knyaz C, Tamura K (2018) MEGA X: molecular evolutionary genetics analysis across computing platforms. Molecular Biology and Evolution 35, 1547-1549.

40. Perna NT, Kocher TD (1995) Patterns of nucleotide composition at fourfold degenerate sites of animal mitochondrial genomes. Journal of molecular evolution 41, 353-358.

41. Zhang D (2020) PhyloSuite: an integrated and scalable desktop platform for streamlined molecular sequence data management and evolutionary phylogenetics studies. Molecular Ecology Resources 20, 348-355.

42. Katoh K, Misawa K, Kuma K, Miyata T (2002) MAFFT: a novel method for rapid multiple sequence alignment based on fast Fourier transform. Nucleic Acids Res 30, 3059-3066.

43. Hall TA (1999) BioEdit: a user-friendly biological sequence alignment editor and analysis program for windows 95/98/NT, Nucleic Acids Symp 41, 95-98.

44. Talavera G, Castresana J (2007) Improvement of phylogenies after removing divergent and ambiguously aligned blocks from protein sequence alignments. Systematic Biology 56, 564-577. 
45. Nguyen LT, Schmidt HA, Von Haeseler A, Minh BQ (2015) IQ-TREE: a fast and effective stochastic algorithm for estimating maximum-likelihood phylogenies. Molecular Biology and Evolution 32, 268-274.

46. Ronquist F (2012) MrBayes 3.2: efficient Bayesian phylogenetic inference and model choice across a large model space. Systematic Biology 61 , $539-542$.

47. Nylander JA, Ronquist F,Huelsenbeck, JP, Nieves-Aldrey J (2004) Bayesian phylogenetic analysis of combined data. Biol 53 47-67.

48. Cameron SL, Whiting MF(2007) Mitochondrial genomic comparisons of the subterranean termites from the Genus Reticulitermes (Insecta: Isoptera: Rhinotermitidae). Genome 50, 188-202.

49. Wan X, Kim MI, Kim MJ, Kim I (2012) Complete mitochondrial genome of the free-living earwig, Challia fletcheri (Dermaptera: Pygidicranidae) and phylogeny of Polyneoptera. PloS One 7, e42056.

50. Dotson EM, Beard CB (2001) Sequence and organization of the mitochondrial genome of the Chagas disease vector, Triatoma dimidiata. Insect Molecular Biology 10, 205-215.

51. Zheng BY, Cao LJ, Tang P, Van Achterberg K, Hoffmann AA, Chen HY (2018) Gene arrangement and sequence of mitochondrial genomes yield insights into the phylogeny and evolution of bees and sphecid wasps (hymenoptera: apoidea). Molecular Phylogenetics \& Evolution 124, 1-9.

52. Riedel F (2000) Ursprung und Evolution der" höheren" Casenogastropoda: eine paläobiologische Konzeption. Vol. 32 (Fachbereich Geowissenschaften, FU Berlin, .

53. Kantor IY (2002) Morphological prerequisites for understanding neogastropod phylogeny. Bollettino Malacologico 161-174.

54. Puillandre N (2008) Starting to unravel the toxoglossan knot: molecular phylogeny of the "turrids"(Neogastropoda: Conoidea). Molecular Phylogenetics and Evolution 47, 1122-1134.

55. Oliverio M, Modica MV (2010) Relationships of the haematophagous marine snail Colubraria (Rachiglossa: Colubrariidae), within the neogastropod phylogenetic framework. Zoological Journal of the Linnean Society $158,779-800$.

56. Hayashi S (2005) The molecular phylogeny of the Buccinidae (Caenogastropoda: Neogastropoda) as inferred from the complete mitochondrial 16S rRNA gene sequences of selected representatives. Molluscan Research 25, 85-98.

\section{Tables}


Table 1. List of 63 Neogastopoda species and 3 outgroups used in this paper.

\begin{tabular}{|c|c|c|c|c|}
\hline Species & Superfamily & Family & Length(bp) & Accession No. \\
\hline Aeneator elegans & Buccinoidea & Buccinidae & 15254 & NC_039120.1 \\
\hline Aeneator recens & Buccinoidea & Buccinidae & 15264 & NC_039122.1 \\
\hline Buccinulum fuscozonatum & Buccinoidea & Buccinidae & 15246 & NC_039121.1 \\
\hline Antarctoneptunea benthicola & Buccinoidea & Buccinidae & 15229 & NC_039119.1 \\
\hline Kelletia lischkei & Buccinoidea & Buccinidae & 15225 & NC_039123.1 \\
\hline Penion ormesi & Buccinoidea & Buccinidae & 15237 & MH198169.1 \\
\hline Penion sulcatus & Buccinoidea & Buccinidae & 15227 & NC_037185.1 \\
\hline Penion maximus & Buccinoidea & Buccinidae & 15249 & NC_037237.1 \\
\hline Buccinum undatum & Buccinoidea & Buccinidae & 15265 & NC_040940.1 \\
\hline Neptunea arthritica & Buccinoidea & Buccinidae & 15256 & KU246047.1 \\
\hline Siphonalia subdilatata & Buccinoidea & Buccinidae & 15393 & MG827217.2 \\
\hline Cominella adspersa & Buccinoidea & Buccinidae & 15251 & NC_039125.1 \\
\hline Fusinus longicaudus & Buccinoidea & Fasciolariidae & 16319 & NC_045906.1 \\
\hline Hemifusus tuba & Buccinoidea & Melongenidae & 15483 & MN462591.1 \\
\hline Nassarius festivus & Buccinoidea & Nassariidae & 15195 & NC_037607.1 \\
\hline Nassarius fraterculus & Buccinoidea & Nassariidae & 15174 & NC_037604.1 \\
\hline Reticunassa hiradoensis & Buccinoidea & Nassariidae & 15194 & NC_037887.1 \\
\hline Reticunassa festiva & Buccinoidea & Nassariidae & 15172 & MG744570.1 \\
\hline Nassarius variciferus & Buccinoidea & Nassariidae & 15269 & NC_029173.1 \\
\hline Nassarius glans & Buccinoidea & Nassariidae & 15296 & NC_049091.1 \\
\hline Nassarius sinarus & Buccinoidea & Nassariidae & 15325 & NC_041545.1 \\
\hline Nassarius javanus & Buccinoidea & Nassariidae & 15325 & NC_041547.1 \\
\hline Nassarius foveolatus & Buccinoidea & Nassariidae & 15343 & NC_041546.1 \\
\hline Nassarius hepaticus & Buccinoidea & Nassariidae & 15732 & MH885313.1 \\
\hline Nassarius conoidalis & Buccinoidea & Nassariidae & 15332 & NC_041310.1 \\
\hline Nassarius siquijorensis & Buccinoidea & Nassariidae & 15337 & NC_048962.1 \\
\hline Nassarius pullus & Buccinoidea & Nassariidae & 15278 & NC_041311.1 \\
\hline Tritia obsoleta & Buccinoidea & Nassariidae & 15263 & DQ238598.1 \\
\hline Columbella adansoni & Buccinoidea & Columbellidae & 16272 & KP716637.2 \\
\hline Amalda northlandica & Olivoidea & Ancillariidae & 15354 & GU196685.1 \\
\hline Babylonia formosae & Unassigned & Babayloniidae & 16214 & MK577482 \\
\hline Babylonia zeylanica & Unassigned & Babayloniidae & 16181 & MN604402 \\
\hline Babylonia lutosa & Unassigned & Babayloniidae & 15346 & KF897830.1 \\
\hline Babylonia areolata & Unassigned & Babayloniidae & 15445 & HQ416443.1 \\
\hline Conus quercinus & Conoidea & Conidae & 16430 & KY609509.1 \\
\hline Conus betulinus & Conoidea & Conidae & 16240 & MG924728.1 \\
\hline Conus gloriamaris & Conoidea & Conidae & 15774 & KU996360.1 \\
\hline Conus consors & Conoidea & Conidae & 16112 & KF887950.1 \\
\hline Lilliconus sagei & Conoidea & Conidae & 15485 & KX263255.1 \\
\hline Profundiconus teramachii & Conoidea & Conidae & 15279 & KX263256.1 \\
\hline
\end{tabular}

Page $8 / 13$ 


\begin{tabular}{|c|c|c|c|c|}
\hline Clavatula tripartita & Conoidea & Clavatulidae & 15743 & МH308391.1 \\
\hline Fusiturris similis & Conoidea & Fusiturridae & 15595 & EU827197.1 \\
\hline Oxymeris dimidiata & Conoidea & Terebridae & 16513 & NC_013239.1 \\
\hline Boreotrophon candelabrum & Muricoidea & Muricidae & 15265 & NC_046505.1 \\
\hline Ceratostoma burnetti & Muricoidea & Muricidae & 15334 & NC_046569.1 \\
\hline Ceratostoma rorifluum & Muricoidea & Muricidae & 15338 & NC_046526.1 \\
\hline Ocinebrellus falcatus & Muricoidea & Muricidae & 15326 & NC_046052.1 \\
\hline Ocinebrellus inornatus & Muricoidea & Muricidae & 15324 & NC_046577.1 \\
\hline Bolinus brandaris & Muricoidea & Muricidae & 15380 & EU827194.1 \\
\hline Murex trapa & Muricoidea & Muricidae & 15408 & MN462589.1 \\
\hline Chicoreus torrefactus & Muricoidea & Muricidae & 15359 & NC_039164.1 \\
\hline Concholepas concholepas & Muricoidea & Muricidae & 15495 & JQ446041.1 \\
\hline Reishia clavigera & Muricoidea & Muricidae & 15285 & DQ159954.1 \\
\hline Rapana venosa & Muricoidea & Muricidae & 15271 & KM213962.1 \\
\hline Menathais tuberosa & Muricoidea & Muricidae & 15294 & KU747972.1 \\
\hline Cymbium olla & Volutoidea & Volutidae & 15375 & EU827199.1 \\
\hline Melo melo & Volutoidea & Volutidae & 15721 & MN462590.1 \\
\hline Neptuneopsis gilchristi & Volutacea & Volutidae & 15312 & MN125492.1 \\
\hline Splendrillia $s p$ & Conoidea & Drilliidae & 15358 & МH308395.1 \\
\hline Lophiotoma cerithiformis & Conoidea & Turridae & 15380 & DQ284754.1 \\
\hline Gemmuloborsonia moosai & Conoidea & Turridae & 15541 & NC_038183.1 \\
\hline Bivetiella cancellata & Volutoidea & Cancellariidae & 16648 & NC_013241.1 \\
\hline Costapex sp & Turbinelloidea & Costellariidae & 15321 & MW044625.1 \\
\hline Haliotis rufescens & Haliotoidea & Haliotidae & 16646 & NC_036928.1 \\
\hline Lottia digitalis & Lottioidea & Lottiidae & 26835 & DQ238599.1 \\
\hline Haliotis rubra & Haliotoidea & Haliotidae & 16907 & AY588938.1 \\
\hline
\end{tabular}

Table 2. Genome composition of two newly sequenced Babayloniidae species (Babylonia formosae and Babylonia zeylanica) 


\begin{tabular}{|c|c|c|c|c|c|c|c|c|c|c|c|c|c|c|c|}
\hline Region & Size(bp) & $A(\%)$ & $\mathrm{T}(\%)$ & $\mathrm{G}(\%)$ & $\mathrm{C}(\%)$ & $\mathrm{A}+\mathrm{T}(\%)$ & $\begin{array}{l}\text { AT- } \\
\text { skew }\end{array}$ & $\begin{array}{l}\text { GC- } \\
\text { skew }\end{array}$ & Size(bp) & $A(\%)$ & $\mathrm{T}(\%)$ & $\mathrm{G}(\%)$ & $C(\%)$ & $\mathrm{A}+\mathrm{T}(\%)$ & $\begin{array}{l}\text { AT- } \\
\text { skel }\end{array}$ \\
\hline Mitogenome & 16214 & 29 & 36.7 & 17.3 & 17.3 & 65.41 & -0.122 & 0.002 & 16181 & 29.4 & 37 & 16.8 & 16.9 & 66.32 & -0.1 \\
\hline $\operatorname{cox} 1$ & 1512 & 26 & 37 & 18.9 & 18.2 & 62.96 & -0.174 & 0.018 & 1533 & 26 & 37.8 & 18.5 & 17.7 & 63.8 & $-0.1 i$ \\
\hline $\operatorname{cox} 2$ & 666 & 28 & 35 & 19.5 & 17.7 & 62.76 & -0.115 & 0.048 & 687 & 29.4 & 34.2 & 18.6 & 17.8 & 63.61 & $-0.0^{\circ}$ \\
\hline atp8 & 156 & 35 & 35.9 & 12.8 & 16.7 & 70.52 & -0.018 & -0.130 & 159 & 35.2 & 36.5 & 13.2 & 15.1 & 71.7 & $-0.0^{\prime}$ \\
\hline atp6 & 675 & 25 & 39.6 & 16.9 & 18.4 & 64.75 & -0.222 & -0.042 & 696 & 26.6 & 38.9 & 15.4 & 19.1 & 65.52 & $-0.1 i$ \\
\hline $\operatorname{cox} 3$ & 774 & 21 & 39.2 & 23.8 & 16.4 & 59.82 & -0.309 & 0.183 & 780 & 22.1 & 38 & 22.6 & 17.4 & 60 & -0.21 \\
\hline nad3 & 351 & 22 & 42.2 & 21.9 & 14 & 64.11 & -0.316 & 0.222 & 354 & 24 & 44.1 & 20.1 & 11.9 & 68.08 & $-0.2^{\prime}$ \\
\hline nad1 & 894 & 23 & 40.8 & 19.1 & 16.6 & 64.32 & -0.270 & 0.072 & 942 & 25.3 & 41.2 & 17.3 & 16.2 & 66.46 & -0.2 \\
\hline nad5 & 1671 & 27 & 37.3 & 13.9 & 22 & 64.09 & -0.163 & -0.227 & 1731 & 28.3 & 37.3 & 13.5 & 20.9 & 65.57 & $-0.1:$ \\
\hline nad4 & 1347 & 28 & 37.7 & 14.3 & 20.3 & 65.4 & -0.153 & -0.176 & 1374 & 28.4 & 38.2 & 13.8 & 19.6 & 66.59 & -0.1 . \\
\hline nad4l & 264 & 28 & 38.3 & 15.5 & 18.6 & 65.91 & -0.161 & -0.089 & 297 & 31.3 & 37.7 & 15.2 & 15.8 & 69.02 & $-0.0^{\prime}$ \\
\hline nad6 & 447 & 23 & 47.2 & 13.7 & 16.6 & 69.8 & -0.353 & -0.096 & 498 & 25.1 & 44.6 & 11.7 & 18.7 & 69.68 & $-0.2 i$ \\
\hline cob & 1119 & 25 & 37 & 15.7 & 21.8 & 62.47 & -0.185 & -0.162 & 1140 & 25.4 & 38.6 & 16.1 & 20 & 63.95 & -0.21 \\
\hline nad2 & 930 & 27 & 38.3 & 20.2 & 14.8 & 64.95 & -0.179 & 0.153 & 1056 & 28.7 & 39.4 & 18.1 & 13.8 & 68.08 & -0.1 ! \\
\hline tRNAs & 1483 & 34 & 32.6 & 19.1 & 14.2 & 66.69 & 0.023 & 0.146 & 1485 & 34.2 & 32.7 & 19.2 & 13.9 & 66.87 & 0.02 \\
\hline rRNAs & 2281 & 37 & 31.8 & 18.3 & 12.9 & 68.83 & 0.076 & 0.173 & 2274 & 37.1 & 32 & 17.9 & 13 & 69.08 & 0.07 \\
\hline PCGs & 10806 & 26 & 38.4 & 17.3 & 18.6 & 64.05 & -0.198 & -0.037 & 11247 & 26.9 & 38.6 & 16.5 & 18 & 65.52 & $-0.1^{\circ}$ \\
\hline
\end{tabular}

Table 3. Start/Stop codons of protein-coding genes (PCGs) from Babayloniidae species (Babylonia formosae and Babylonia zeylanica)

$$
\text { Babylonia formosae Babylonia zeylanica }
$$

Species

\begin{tabular}{lllll} 
PCGs & Start & Stop & Start & Stop \\
\hline cox1 & ATG & TAA & ATG & TAA \\
\hline cox2 & ATG & TAA & ATG & TAA \\
\hline atp8 & ATG & TAA & ATG & TAA \\
\hline atp6 & ATG & TAA & ATG & TAG \\
\hline nad1 & ATG & TAG & ATG & TAA \\
\hline nad6 & ATT & TAG & ATT & TAA \\
\hline cob & ATG & TAA & ATG & TAA \\
\hline nad4I & ATG & TAG & ATG & TAG \\
\hline nad4 & ATG & TAA & ATT & TAA \\
\hline nad5 & ATT & TAA & ATT & TAA \\
\hline cox3 & ATT & TAA & ATG & TAG \\
\hline nad3 & ATG & TAA & ATG & TAA \\
\hline nad2 & ATG & TAA & ATT & TAA
\end{tabular}


A

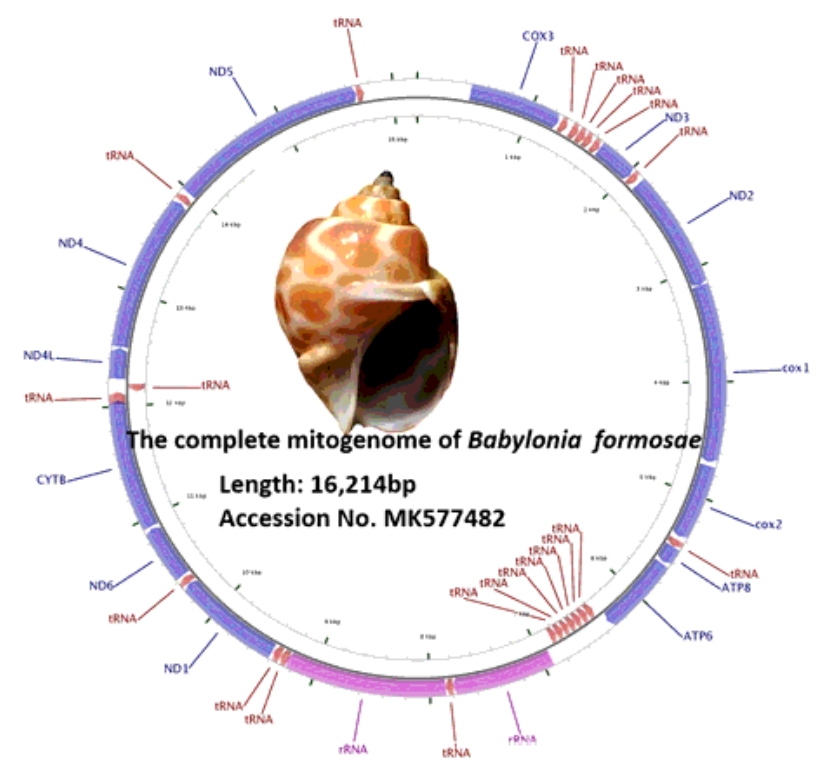

B

率

\section{Figure 1}

Maps of the mitochondrial genomes of two Babylonia species (B. formosae (A) and B. zeylanica (B))
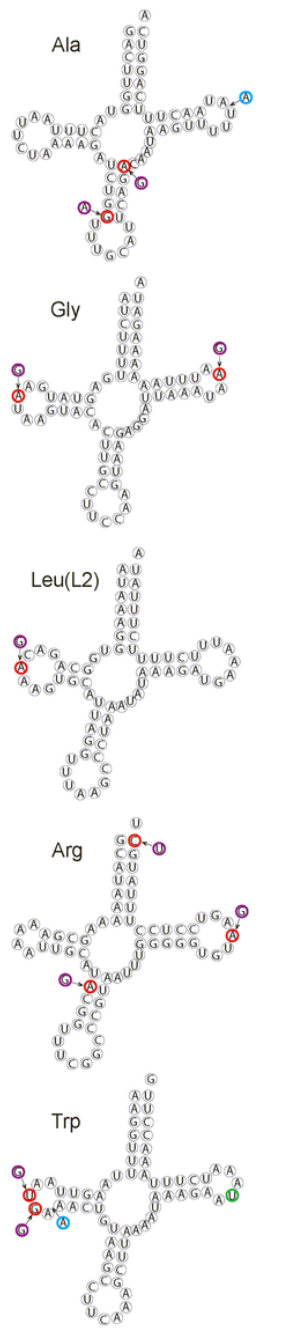
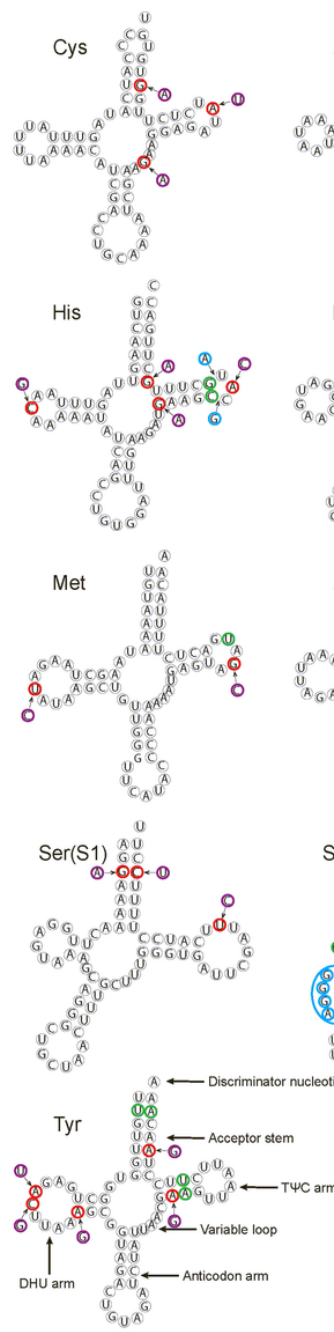
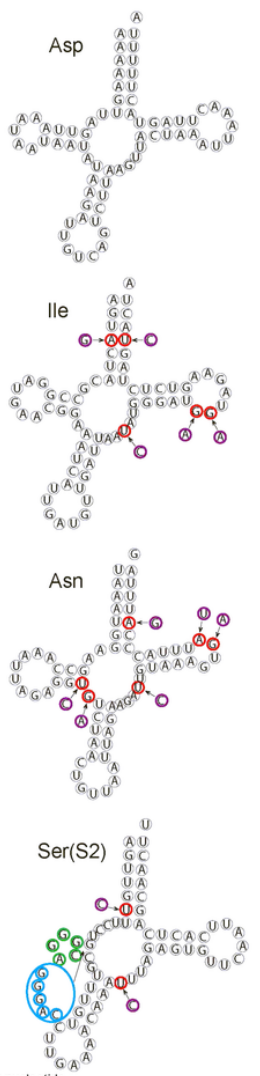

(N) Identical in two species
(N) B.formosae
(N) B.zevlanica
(N) Insertion in B.formosae
(N) Exist in B.zevlanica, lacking
in B.formosae

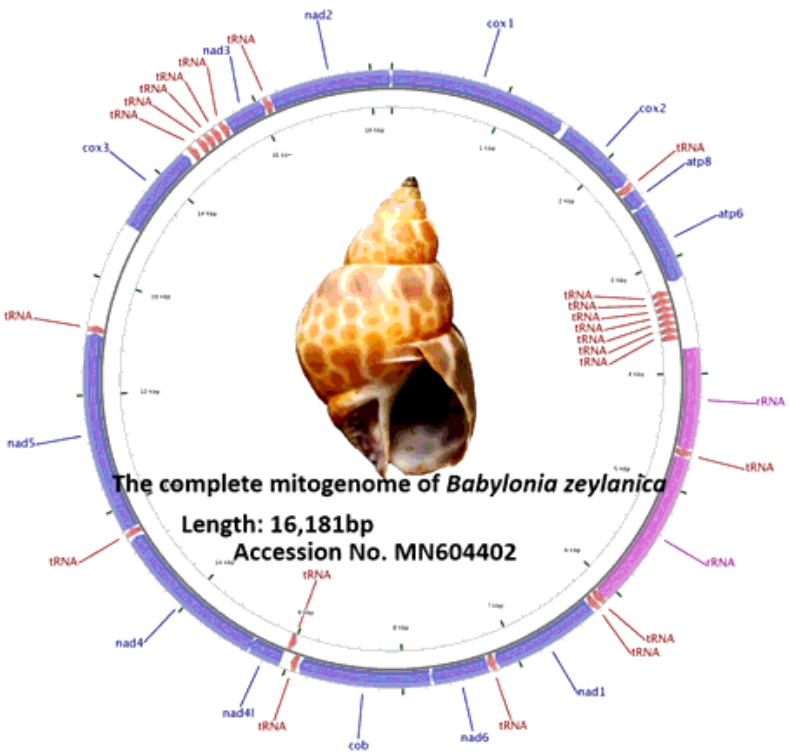

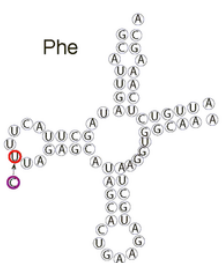
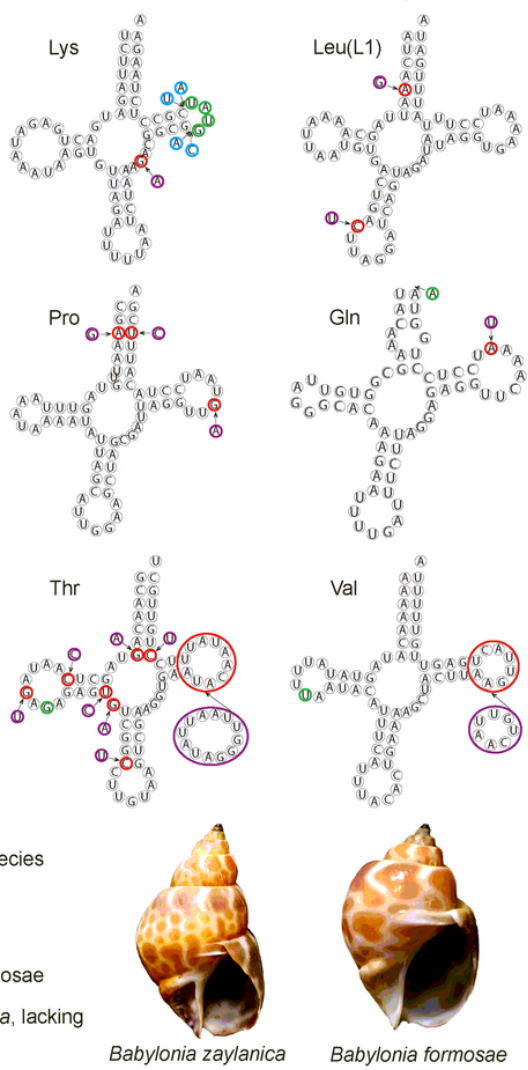
Figure 2

Secondary structure of tRNAs of B. formosae and B. zeylanica

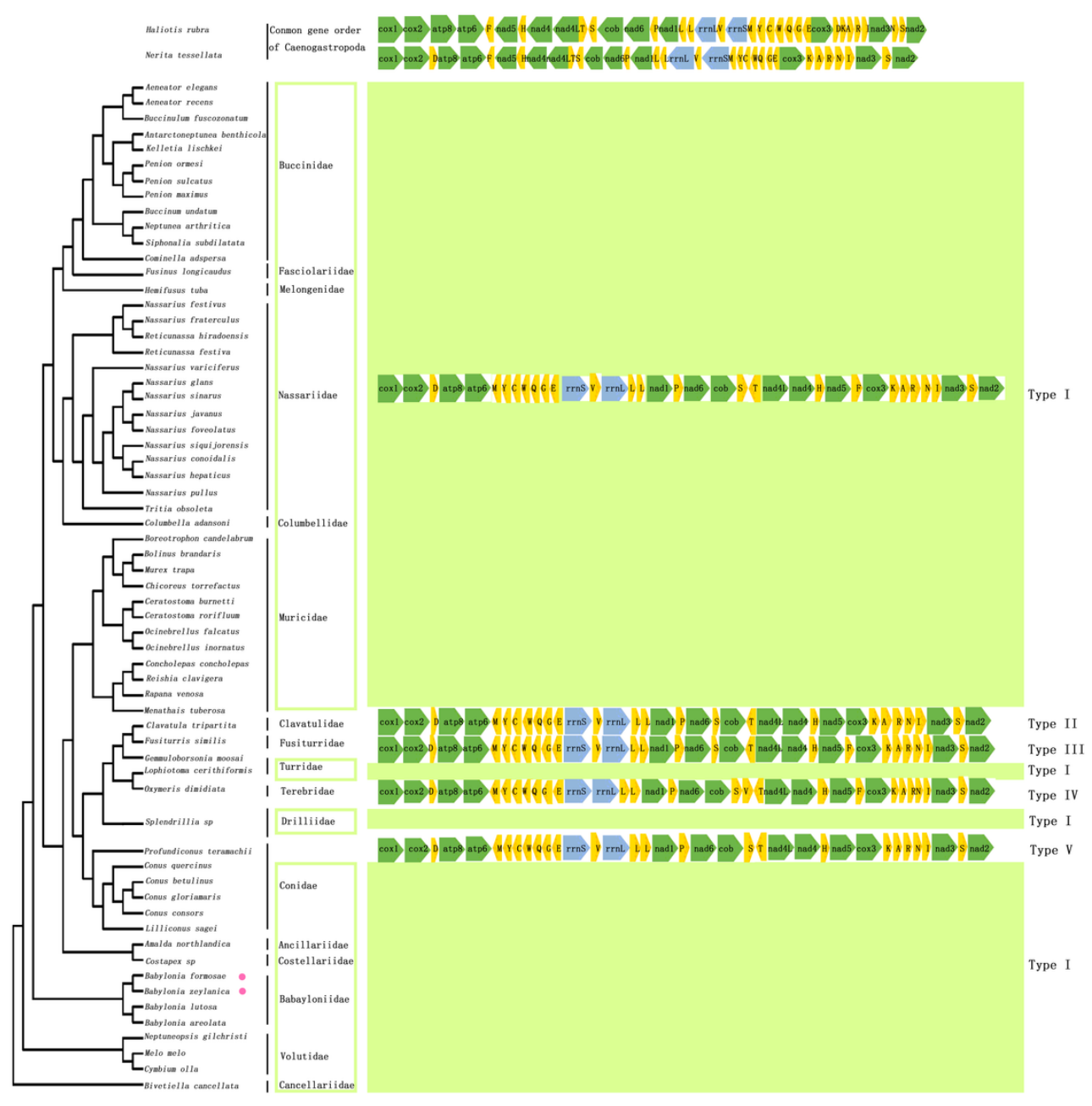

\section{Figure 3}

Mitochondrial genome organization of the two new Babyloniidae species and mitochondrial gene arrangement pattern of seventeen major lineage of Neogastropoda. The topology was generated from phylogenetic analysis. The direction of the arrows indicates the strand orientation ("+strand" to the right and "- strand" to the left; and the light green boxes on the outside indicate that the species are in the same gene order). 


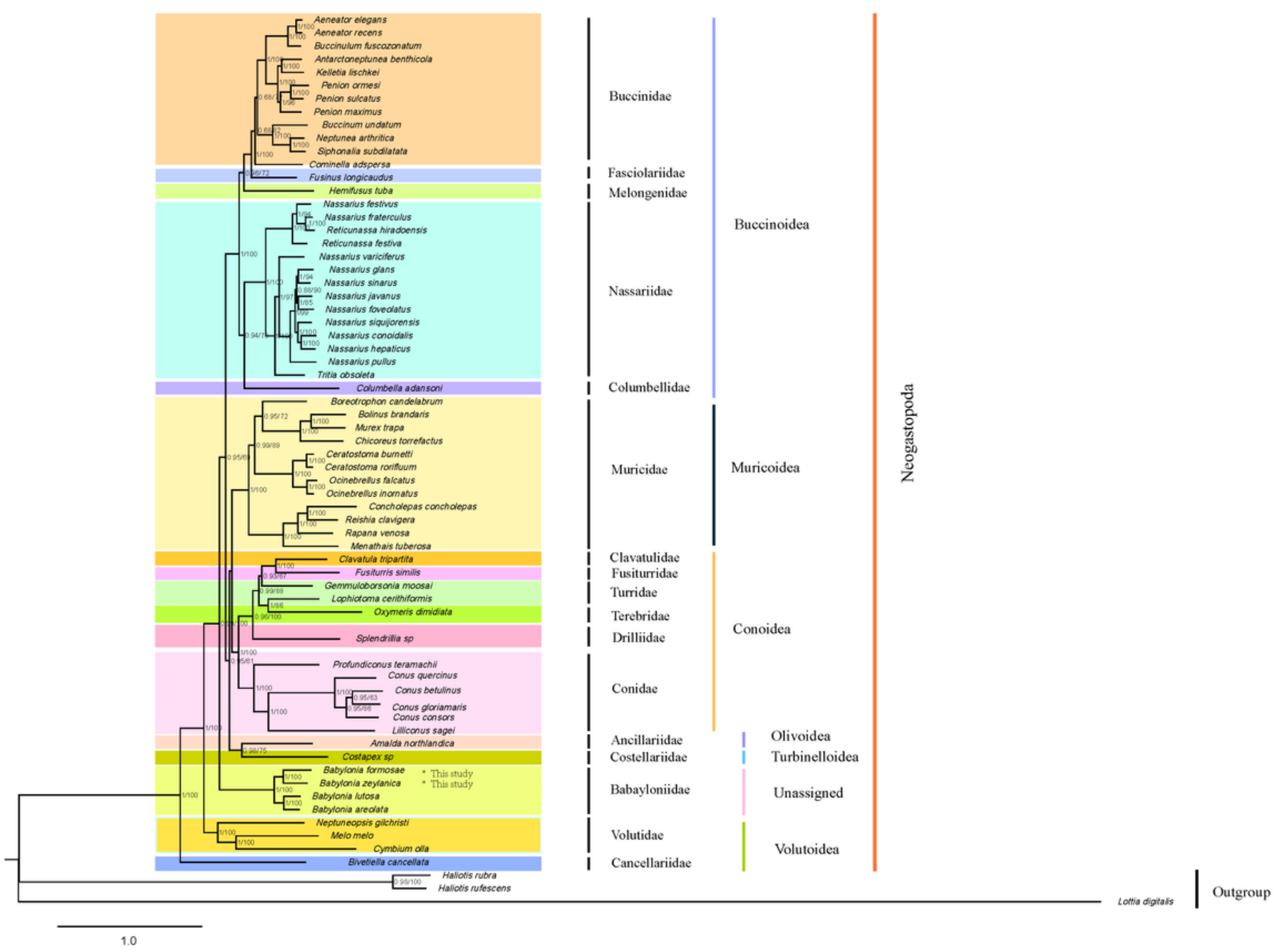

\section{Figure 4}

Phylogeny of Neogastropoda based on nucleotide sequences. The phylogenetic tree was inferred from the nucleotide sequences of 13 mitogenome PCGs using $\mathrm{BI}$ and $\mathrm{ML}$ methods. Numbers on branches indicate posterior probability. The different colored lines represent the families and superfamilies of these species. Rectangles with different background colors are used to distinguish different families. 